\title{
A Model of Humanistic Religious Understanding: A Study of the Thoughts of Abdurahman Wahid
}

\author{
Elis Teti Rusmiati ${ }^{1}$ \\ \{elistetirusmiati@dsn.moestopo.ac.id ${ }^{1}$ \} \\ Universitas Prof. Dr. Moestopo (Beragama) $^{1}$
}

\begin{abstract}
This study discusses the phenomenon of the fading humanistic side in terms of the religiousness of people and the phenomenon of various conflicts, disintegrations, and disputes emerging in the name of religion. This study analyzes the model of humanistic understanding of religion from the thoughts of Abdurrahman Wahid (Gus Dur). This study is vital since the fading of the humanistic side emerges the ambivalent face of religion which becomes legitimacy for destructive actions: a reality against its claim as the source of peace and mercy. Religion is then accused as "scapegoat" for integration and considered as the opposite of the changes of life's modernity. This study employs a phenomenology method to analyze the religious social phenomenon and employs a hermeneutic approach in interpreting and analyzing the humanistic thoughts of Gus Dur. The result of the study is that, religious critical logic of the Indonesian people has not been constructed so that religiousness emphasizes more on symbols than meanings. As a result, that religions are not able to participate in dialogue with culture and modernity, the face of religion isn't appealing/interesting. The Humanism philosophy of Gus Dur rejects the dialectics in which ideological substance become the reference to other values and ideologies. For Gus Dur, humanism is the most important value of all religions; it calls upon the religious people to practice religion through more than just religious symbols and practices.
\end{abstract}

Keywords: model of understanding, Abdurrahman Wahid, religion, humanism, religiousness

\section{Introduction}

The historicity of Religion emerges as a reaction and deconstruction to the totalitarian, authoritative, dictatorship system and all systems of life that throws human beings into the object of an sich authority so that his existence, honor, and dignity are no longer respected. Religions are born to liberate a human beings from sufferings, stupidity, and even suppression/tyranny. The central message of these liberating values is contained clearly in various holy books such as the Koran, Bible, Torah, Veda and other holy books full of the divine teachings, universal humanism morality, and human dignity. The emphasis on human being liberation puts religion at the opposite side of immoral and inhumane forces. Religion becomes the adversary of tyranny, injustice, violation of human rights, and other immoral actions. 
In history, Islam was born in 612AD in the period of an ignorant Arab society (the age of stupidity/darkness) who was not familiar with humanity and suppressed each other [1]. The religion brought by Jesus was born in the middle of injustice and cruelty of King Herod that the crucifix ended the struggle of Jesus. Protestant emerges as the result of church reform triggered by various situations, from politics, economic transitions, bad morality values, and hegemony of Catholic church over Nation. Christianity became the formal religion of Roman Empire (15th Century). In such manner Buddhism was born, when the social-political condition of India was at anxious time where people suffered, although the Royals lived in luxury.

All religions are fundamentally good and encourage goodness. In essence, the presence of religion is for the goodness of humankind. However, in reality, not all deemed good can meet and go along all together. Once in a while, one "goodness" of one religion goes against the "goodness" from other religions. In this position, the truth can no longer be understood as one/single.

Friction occurs when those outside one's religion are regarded as misguided and infidel who do not deserve to go to heaven. In the end, In the name of religion, people blame each other, strike each other, and even kill each other. In the particular understanding, religion is used as ideological and theological legitimating-base for destructive actions.

In this matter, many examples happen in Indonesia. For instance, in 2014, there are eight cases of religion related violence in Yogyakarta: intimidation to RaustanFikr group in Sleman; anti Shi'a declaration in Universitas Gadjah Mada campus mosque; violence against the Head of GunungKidul Cross-Religions Forum; dismissal of Shi'a group meeting in Bantul; violent actions against Adisyuswa Easter in GunungKidul; violence and attack against Catholic community in Ngaglik, Sleman; mistreatment of Julius Felicianus, director of Galang; and attack on Pentecost place of reverence in Pangukan, Tridadi, Sleman [2].

Conflict in the name of religion occurred in October 2015 in Aceh, causing the life of one and the burning of a church by mass of hundreds of people. The conflict was triggered by the permit for constructing church in the area. In July 2015, the Eid al Fitr atmosphere in Tolikara Regency, Papua, was torn by a conflict between the majority and minority in the area causing a lot of victims [2].

This destructive face of religion becomes worse when it on the other hand seems incapable to have dialogues with the development of modernity and science, and is intolerant, and at the opposite side of Human Rights. The ugly face of religion gets further worsened by the appearance of religious figures that are inclined to judge easily without sufficient explanation and promise consolation beyond common sense.

In the end, agnosticism (believed as a concept of believing God's existence without believing in any religion), becomes the option of many people starting to contemplate on the presence of religion. With the paradox faces of religion as is mentioned before, Agnostic believes that religion is not a guarantee of heaven. In the view of an agnostic (Interview result with VinaArventia, A student of Universitas Prof. Dr. Moestopo Beragama Jakarta, 14 April 2016), religion is analogized as "vehicle in garage" if it is only recorded on an Identification Card. Without fuel, a vehicle is just a heap of metal unable to take people towards the destination. Religion without good thoughts, words, and actions will not deliver human into heaven. If people acclaimed to have religion think of themselves as more wise than agnostic and atheist, why then there are still 'pious' people, even with religious title, who conduct unworthy deeds?

The condition explained above gives the conclusion that the hablumminannas (human relation with each other) teaching as the core of religious teachings becomes unpopular. 
Meanwhile, hablumminallah (human relationship with Allah) teaching is the primary face of Indonesian Muslim almost without any connection to hablumminannas.

With this background, the problems to be studied in this paper are: 1) Which factors cause the fading of humanistic side in the religious manner of Indonesian people? 2) What is Gus Dur thought concerning the model of humanistic religious understanding in the context of Indonesian people?

Gus Dur is an Indonesian figure who calls for pluralism, democracy, human rights and civil society movements on the basis of humanism. For Gus Dur, the real role of religion is to make people realize the fact of themselves as a part of humankind and the universe. Therefore, Gus Dur believes, it does not matter what religion or ethnic group someone is from, if he can do goodness for the sake of many, he will not be asked what his religion is or from which ethnic group he comes [3].

Humanism, Gus Dur believes, is also the vital core of politics. Political movement performed by Gus Dur is implanting and raising tolerance values in the middle of complexity of religions, races, and ethnic groups in Indonesia which become one force in upholding just, democratic, and anti violence State order.

This study is vital to conduct to criticize and discover the root of the problems which turns the face of religion into paradox, ambivalence and destruction: a condition in the direct opposite of the primary goal of religion as savior and guide of human life. Then, the model of humanistic religious understanding derives from the thoughts of Gus Dur is selected as model.

\section{Method}

To find the accurate understanding of the social phenomenon in the fading of religion's humanistic side and emergence of various conflict, discord, and dispute in the name of religion, this study employs phenomenological method. The fundamental concept of phenomenological study, one of which is influenced by Max Weber (1864), emphasizes on verstehen, namely interpretative meaning of human understanding. In this matter, verstehen is a method of approach trying to understand and comprehend the meaning behind social and historical occurrences or phenomenon. This approach is based on the idea that every social situation is supported by the network of meaning created by the actors involved in it.

One of the most important ideas of phenomenological paradigm employs here is the idea of how a researcher should be in perceiving social reality, social facts, or social phenomenon on the fading of religion's humanistic side and the emergence of various conflicts, discords, and disputes in the name of religion. In phenomenological paradigm, it is believed that reality is not singular, objective, and measurable and can be captured by human senses as is believed by positivism. According to phenomenology, reality has dual natures or dualism, and interpretative- subjective or the result of subjective interpretation.

Phenomenological approach is employed in this study to discover the meaning of phenomenon of life experience. The author gathers data related to the concept, opinion, stance, attitude, judgment, and understanding of situation or experiences in life. This study is aimed at discovering meaning of matters essential or fundamental from religious experiences and attempts to explain or disclose conceptual meaning or experience of the phenomenon based on the awareness of some individuals or group.

Moreover, to understand and obtain accurate interpretation of Gus Dur's thoughts, this study employs the Hermeneutic approach. In hermeneutic, the problems related to text interpretation are: 1) essence and nature of interpretation itself: What is the interpretation of Gus Dur? 2) Concerning subject and realm of interpretation: what can be understood from his 
thoughts? 3) Stressing on the process of an interpretation or interpretation phenomenology creation: How is Gus Dur humanism created; what is the social political situation that creates his thoughts?

\section{Result and Discussion}

Violence is a universal sociological phenomenon. It can transpire at individual, collective, institutional or the entire system levels. The focus of this study is directed at violence originated from or happened in the name of religion or that use religion as justification.

In recent years, Indonesia becomes one of the areas of the world where much violence in the name of religion transpires. According to Sudarto, a Researcher from AliansiNasionalBhinneka Tunggal Ika, since the reform era until the end of the leadership of Susilo Bambang Yudhoyono (SBY), from the 2,392 violence cases transpired, 65 percent or 1,554 cases are originated form religious issue. In the era of the Old Order, there were only 2 cases, while in the era of the New Order it increased to 450 cases and surged to 1,000 cases in the era of reform. In the era of Gus Dur, during the heated conflict in Poso and Ambon, 1,000 places of worship experience this case. In the era of Habibie, there were 200 cases due to its position as the transition era, while in the era of SBY, there are 500 cases. (Accessed http://www.cnnindonesia.com/ Sabtu, 15/11/2014 09:09 am)

Other data discover, until the first half of 2014, there are six violent cases in the name of religion in Central Java. These six cases are among others destruction of Hindu community place of worship in DukuhGiriloka, Sragen District by unknown people, dispute between local citizens and FPI in Wonosobo, dismissal of MajelisTafsir Al-Qur'an (MTA) reciting of Koran in Magetan Village, Demak County, rejection of HabibRizieq in BonangDemak Sub-district, and conflict between Head of Grobogan District with JantikoMantabDzikrul, and the arrest of assumed terrorist in Klaten by Densus 88 Anti Terror (Accessed http://www.suaramerdeka.com $\quad 04$ Juni 2014, 01:38 pm)

The forms of violence in the name of religion are diverse (Violence in the name of Religion: Political Perspective, 2009:1-19). First, violence inside the same religious realm. From the actors involved, there is a variety of patters, among others:

(a) violence involving mass organization of the same religion community.

(b) violence involving the state which acts in the name of formal religion in repressing "lost sect" of a religion.

(c) violence involving communities from the same religion.

(d) violence involving religion authority holder institution over citizens from the same religion.

Second, violence involving different religions. From the actors, there is variety of pattern such as:

(a) violence involving mass organization of one religion towards community from other religion.

(b) violence involving mass organizations from different religions. In this particular case, the violence involved is more verbal or symbolic ones.

(c) violence over religion group involving state through certain arrangements.

Third, violence of one religion group over other group practicing activities deemed inappropriate to the religious teachings. The patterns discovered here are among others:

(a) violence conducted by mass organization over activities deemed as symbols of sinful acts and the likes. 
(b) violence in the name of religion by a community group towards activities accused as symbols of sinful acts and the likes.

Perceived from violence pattern: First, from the level of incidents, two third of religious conflicts in Indonesia are in the form of peaceful acts, and only one third in the form of violent acts. This shows that the people of Indonesia have the capacity to materialize their responds over religious conflicts in the form of peaceful acts.

Second, from the timing, if the three regimes are to be compared, violence incidents happen more often in transitional regime than in the two other regimes. It shows that the opening of citizen participation channel in democratic era after being clogged under the authoritarian New Order regime is not balanced by the good function of security apparatus. This is strengthened by the fact that peace acts following religion conflict seems to be dominant in the new democratic regime.

Third, both in peaceful or violent acts, most of religious conflicts are related to communal issues, such as conflict between Muslim-Christian communities and religion blemishing. However, there are geographical variants concerning issues stimulating conflicts. Communal issues seem to be dominant in the areas indeed known to be the areas of communal conflict, such as Maluku, North Maluku and Central Sulawesi. Meanwhile, in the areas such as West Java and Banten, the religious conflicts transpired involve more morality and sectarian issues. While in DKI Jakarta the religious-nuanced violence involves more on the issues of terrorism and morality.

Fourth, from the actors, citizen group is the most group becoming actor of violence. Meanwhile, religious group is often perceived as the dominant actor when in fact it is only in third position after terrorists. Perception of the dominant involvement of religious group can only be justified in this study in terms of their involvement in peaceful acts.

Fifth, violence related to communal issue is the violence incident taking most victims, both human and goods. Meanwhile, from the loss of goods, morality-related issue is in second position with the biggest loss impact after communal-related issue.

Sixth, from the information gathered, the role of security apparatus in religious conflict incidents is insufficient.

In the early 2016 (http://berita.suaramerdeka.com/ Accessed 11 March 2016, 1.13 p.m), violence in the name of religion transpires in a terrorism case at Sarinah shopping center in Jakarta, taking many victims. The terrorists are often identified as having affiliation with a certain religious network. Some testimonies from the actors even confirm that their actions are motivated by religious motive they interpret as the "holy" calling to die in the path of Allah (jihad). There is a crystallized belief that when they die, they will go to heaven.

Other form of violence is the case of 60 members of Islam Defender Front (FPI) Bekasi attacking eleven obscured stalls at Jalan Masjid Taqwa, Sunday, 21 May 2006. FPI had warned the stalls serving music and alcohol to close, but their numbers are increasing. This convinces FPI that the procedure of upholding amarmakrufnahimungkar and upholding Islam in kaffah (wholly) manner is never really conducted by the Government who even give the permission. Therefore, as the mass organization claiming as upholder of Islamic teachings, FPI feels obligated to conduct firm ways (violence) to emphasize their message. On other incident, 12 April 2006 at about 14.00, around 500 members of FPI come to the office of Playboy magazine in Asean Aceh Fertilizer (AAF) building protesting the publication of the adult magazine.

It is a reality along the history of human being in the past, present, and future that various ideologies, schools of philosophy, teachings, and others appear and disappear. However, religion stays and never dies and disappears, which means that the types of human 
worshipping God will always exist and develop. A religious organization can be dismissed; according to Quraish Shihab [4], the religious community can be expired; yet religion, although not eternal, will exist. Since religion will stay and never disappear, the teachings about God taught within and by religions will also stay. Even if there is no religion, God will always stay, since God is not dependent to the existence of religion.

Religion appears because of the presence of a human being. Human is the creature gifted with perfection in the form of their nature as intrinsic motivator to attain feeling or instinct of curiosity for real essence of life, since with it human has the drive to possess soul-soothing feeling. Religion can only be seen as religion in terms of having impact on whole human alteration when human becomes adherent. Religion means nothing without adherents. Religion will only be gathering of human beings practicing a teaching system if it is not practiced by its adherents. Religion will only have meaning if its adherents practice and apply its teachings well in their daily life.

Why then human has religion? The simple answer is that human has religious instinct to worship something outside him as an obedience to superior power that determines human life namely a bond that unite human thoughts with mysterious thought governing the world and the self he understands, and with matters causing tranquility when bound to them [5].

Joachim Wach [6], an expert of religious sociology, believes that there are two views of the presence of religion inside a society, namely negative and positive views. The previous view states that when religion is present in a community, separation cannot be avoided. In this matter, religion is judged as a disintegrating factor. One of the reasons is that religion present with a set of ritual and belief system which in long term gives birth to a particular community, distinctive to other religion adherent communities. This distinction becomes more intensive when adherents of a religion have achieved attitude and belief that the only truthful religion is theirs. Other religions are wrong and should be treated as enemy.

The second view is on the opposite. Religion in fact plays the role of integrating when society lives in tribes with high tribal sentiment, even with the presence of law of the jungle, religion usually plays the role of giving new and comprehensive bond that buries pieces of old sentiment causing the disintegration. Religion with standard belief system, sacred ritual forms and religious organization in social relation has strong binding power for the integration of society.

In a minor study, several reasons why someone follow a religion and simultaneously develop his religious patterns are discovered; among others are psychological limit and incapacity reason. Human being feels the uncertainty of the future since they cannot go along with changes, so that they have stagnation of thinking, and escape to spiritual matters. There are others who have specific reasons such as wishing to give positive influence to life or with the reason that religious teachings makes human having good morality and ethic attitude, so that they can build relation with each other full of goodness and responsibility.

For whatever reason someone adheres to a religion, in truth, religion plays the role of changing human, and conversely human can be changed because of religion. Therefore, there are some roles religion can take related to its role as religious institution or community, in particular those who plays the role of religious leaders. When someone adheres himself to a certain religion or becomes member of religious community, it implies to him that he has to take advantage of his action. This means that religion must bring total improvement and alteration to human being.

Every religion always brings peace and harmonious life mission, not only among human beings, but also with other God's creations. In the Koran terminology, this holy mission is called rahmatanlilalamin (mercy and peace for the entire universe). In the realization, religious 
holy mission is not always articulate. Sindhunata [7], even states that speaking of religion now is like speaking of a paradox. On one side, religion is experienced as the way and guarantee of safety, love and peace. On the other side, history has proven that religion becomes the source and reason for destruction and misfortune for human kind. Because of religion people can love, but also in the name of religion people can kill and destroy each other.

From several opinions, it can be concluded that religion-related social conflict can be caused by several factors, among others:

1. Claim of truth believed by religious adherent on the basis of their God as the only source of truth. Only, human plurality with various religious belief causes the face of truth seems different when shown.

2. Blurring of perception in the sphere between religion and ethnicity, for instance in the case of Dr. AM Saefuddin, the Minister of Food and Horticulture at the era of President BJ. Habibie, who is considered causing religious and ethnicity turbulence with his comment that Megawati has converted to Hinduism after he saw Megawati participates in ritual activities of Hinduism in Bali.

3. The presence of Jihad doctrine and the lack of tolerance in religious living.

4. Minimum understanding of pluralism ideology.

For Charles Kimball [7] whether a religion is problematic or not does not depend on the religion itself, but its relation to real human life. In other words, human is the standard of whether religion is problematic or not. Therefore, however glorious the teachings of a religion is, however noble its institution is, all of it will only be degrading if the religion only causes suffering for human. Kimball concludes five things or signs that can make religion degrading or corrupt. First, when a religion claims its truth as the absolute and only truth. When this happens, the religion will do anything to justify and support the truth claim. It does not realize that God in reality is "only" the title in human language about the All-Greatness that cannot be captured by the limitation of human language. This truth claim in fact impoverishes and degrades God from the All-Greatness. This, according to Kimball, is human corruption of God's wealth. Unfortunately, this corruption and impoverishment becomes the basis for eliminating other religion adherents, since they are considered as having untrue (wrong) meaning of God.

Second, blind obedience to their religious leader. In its originality, religion never resists the intellectual and freedom of human. Thus, Kimball reminds us to be careful of religious movement that opposes common sense, limits intellectuality, and eliminates individual integrity of its adherents by demanding blind obedience to their charismatic leader. Third is when religion becomes longing of ideal era and determined to manifest it at present. It is indeed true that in essence religion is a wish that in the future its adherents will get and experience something ideal. However, Kimball asserts, if religious vision of the ideal era starts to be manifested and believed by its adherents as the will of God, it is a sign of religion becoming corrupted and evil. This belief usually drives the adherents to form theocratic nation and along the history, in Kimball view, there are many examples of how fatal a theocratic state can be when manifested. In Indonesian context, related to this some cases emerge among others through terrorism, ISIS, and others.

Fourth, on corrupted religion, namely when religion justifies and lets the occurrence of "the goals justify the means". This corruption of religion is related to exploitation of the components of religion itself. Fifth, that religion is becoming corrupted and evil. The example of Kimball in elaborating crime of religion is the truly cruel Crusade, or modern terrorism such as September 11 which takes a lot of innocent victims. 
In connection to violence, Gus Dur states that when people dispute or commit violence in the name of religion, then they worship religion, not Allah. When there are people hating or hurting each other in the name of religion, in truth the one they worship is religion not Allah. For Gus Dur, religion is not more than human regulation for the goodness of human themselves. Therefore, religion does not need to be defended; it is human that should be defended for their humanity.

The religious pendulum-swing heavily depends on the perception and behavior of its adherents which will direct to two sides: humanization or dehumanization. Gus Dur responds to these two sides by stating that Islam is a religion seriously concerns with human rights. Islam's protection over human rights is quite apparent through: 1) the right for living (hifdz alnafs); 2) the right for having religion (hifdz al-din); 3) the right for thinking (hifdz al-aql); 4) the right of possessing (hifdz al-mal); and 5) the right for raising family (hifdzu al-nasl).

Gus Dur's daughter testified that, "when [Gus Dur] stubbornly defends Chinese, Ahmadiyah, Christian and other marginalized people, he does not struggle for Chinese, Ahmadiyah, Christian, or others, but for human kind. Thus, it is more accurate to call Gus Dur as a humanist figure". Inayah says that Gus Dur never calls himself a pluralist, but a humanist. "Gus Dur even once orders that on his tomb inscribed "Here lies a humanist," reveals Inayah, the youngest daughter of Gus Dur which she conveyed during the commemoration of 1,000 days of the pass away of Gus Dur, 15 October 2012).

In essence, the presence of religion is for the goodness of human kind. The teachings of every religion contain a set of rules regulating the well being of human. In Gus Dur assessment, now the face of religiousness becomes lacking of hablumminannas (relation with others) teaching. On the contrary, the hablumminallah (relation with God) teaching becomes the primary focus that annihilates theology relevance in solving social problems. It cannot be avoided that religion in the end brings paradox situation. On one hand religion is experienced as the way to peace and salvation, on the other hand religion becomes the source and reason of social conflict.

In Gus Dur view, the symbolic rituals of religions, as is often accentuated by FPI in their actions, is just "the way to God". The absolute matter is humanistic values as universalism of religions. Therefore, having extreme, extensive fanaticism, and being unfriendly to other religion adherents is not the right thing to do. Thus, humanism should be understood more as the most important part of religions. Humanism invites religious communities beyond the symbols of religions.

Thus, there is a need for revitalization and re-actualization of religious understanding. Critical attitude in understanding the essence of religion is absolutely required. Theologizing, according to Gus Dur, should be conducted by giving adequate portion to humanistic values since in reality humanism is the universalism of religions.

In every religious tradition, theology is perceived as the vital element as the basis of religion. Without theology as the ground for one's belief, there is no religion. Therefore, it can be understood that theology becomes traditional field of study in all religions; even religious history is basically theology. Theology in the perspective of Nurcholish Majid [8] is viewed as a strategic field in the attempt of renewing understanding and development of Islamic community. It is called strategic since theology is the vital aspect that can function as critical reflection of human actions in viewing the social reality he faces [9].

When discussing the matter of relation between God and human, the mainstream theological thinking is always theocentric (God as the center of force/power and human must submit to and obey God). This view regards religion as the way human worshipping God, a theology that invites human to leave everything for God. Therefore, God not just create 
human, but also intervenes, visits, and reigns in earthly living. Therefore, human lives in passive, linear, status quo, monotonic life which is the absolute shape of scenario [10].

This theocentric theology, although has positive impact according to NurcholisMajid, in actuality has hazardous subside effect, namely personal shackling and deteriorating of human dignity. In the midst of many problems, theocentric theology stays still. This theology even becomes a device to oppress human. Therefore, it takes a critical logic to "humanize theology and theologize human" [9], so that shifting of paradigm in theology becomes certainty.

Thus, Gus Dur believes, there is a necessity for a critical understanding which places anthropocentric paradigm, a theology putting human as the center of orientation (theology as the core of humanizing and saving), as the center/core in understanding religion. However, anthropocentricism here is quite clearly not secular-anthropocentric theology where human as the righteous king who exploit nature on the basis of profit-loss for his needs. It is dialogicanthropocentric theology materialized in daily life; someone believing God is in himself humanitarian. Thus, anthropocentric theology does not mean to alter Tauhid (unity of God), but an attempt to revitalize and re-actualize religious understanding. At this point, the author appraises Gus Dur's humanism as Religious-Humanism [11].

Positioning of God as the first and primary destination (theocentric) when not accompanied by critical logic can deliver an attitude of always concentrating on the effort of reaching God's consent and is inclined to have the "impression" of ignoring all but God. It is complicated when this understanding is not accompanied by adequate religious knowledge, it will shift (ignore) humanistic values, although God brings religion for the need of human so that human can be more appreciative of humanistic values. In fact, this humanistic potential is the thing God enlarges in human from other creatures.

For Gus Dur, this kind of religious perspective shows that there is something "wrong" with the way of theologizing thus far. Therefore, it is very relevant to rethink of theological context view that can really esteem humanistic values. Religion is acknowledged as the belief (involving feeling) on one side, but critical logic of being religious must still be constructed to prohibit religion from losing direction. In other words, it directs theocentric theology into the way of theologizing which raises humanistic spirits so that it does not deliver the inclination of religious behaviors that hides behind the name of executing the command of God, but degrading humanistic values.

\section{Conclusion}

The results of the study shows that: Religious critical sense of Indonesian people has not been constructed so that religiosness emphasizes more on symbol rather than meaning. As a result, that religions are not able to participate in dialogue with culture and modernity, the face of religion isn't appealing/interesting.

The Humanism philosophy of Gus Dur rejects the dialectics in which ideological substance and Islamic values becomes the reference to other values and ideologies, such as modernism, nationalism and socialism. For Gus Dur, humanism is the most important value of all religions; it calls upon the religious people to practice religion through more than just religious symbols and practices. In civic life, the humanism Gus Dur proposes heads towards the forming of civil society that is constituted by the consciousness of citizen's rights through three pillars: democracy, justice and equality before the law. 


\section{References}

[1] A. Hanafi, Pengantar Teologi Islam. Jakarta: Pustaka al-Husna, 1992.

[2] Nurhadi and W. Izzuddin, Kala Agama Menjadi Bencana. Bandung: Mizan, 2013.

[3] G. Barton, Abdurrahman Wahid: Muslim Democrat, Indonesian President. Sydney: University of New South Wales Press, 2002.

[4] K. Hidayat, Agama Punya Seribu Nyawa. Jakarta: Noura, 2012.

[5] E. Durkheim, "The Elementary Forms of the Religious Life, trans. Inyiak Ridwan Muzir, Yogyakarta: IRCiSoD,” 2011.

[6] W. Joachim, Sosiology of Religion. Chicago and London: University of Chicago Press, 1971.

[7] C. Kimball, Nurhadi, and W. Izzuddin, "Kala Agama Menjadi Bencana.” Mizan, Bandung, 2013.

[8] N. Majid, Iman dan Emansipasi Harkat dan Martabat Kemanusiaan, dalam Islam Doktrin dan Peradaban. Jakarta: Paramadina, 2000.

[9] Rumadi, Masyarakat Post-Teologi Wajah Baru Agama dan Demokrasi Indonesia. Jakarta: Mustika Bahraid, 2000.

[10] A. Pribadi and M. Haryono, Post Islam Liberalisasi, Membangun Dentuman Mentradisikan Eksperimentasi. Jakarta: Pasirindo Bangamas Nagari, 2002.

[11] S. Arif, Humanisme Gus Dur, Pergumulan Islam dan Kemanusiaan. Yogyakarta: ArRuzz Media, 2013. 